University of Nebraska - Lincoln

DigitalCommons@University of Nebraska - Lincoln

1983

Seed Predation and Seedling Mortality in the Recruitment of a

Shrub, Haplopappus venetus (Asteraceae), along a Climatic Gradient

Svata M. Louda

University of Nebraska - Lincoln, slouda1@unl.edu

Follow this and additional works at: https://digitalcommons.unl.edu/bioscilouda

Part of the Ecology and Evolutionary Biology Commons

Louda, Svata M., "Seed Predation and Seedling Mortality in the Recruitment of a Shrub, Haplopappus venetus (Asteraceae), along a Climatic Gradient" (1983). Svata M. Louda Publications. 16.

https://digitalcommons.unl.edu/bioscilouda/16

This Article is brought to you for free and open access by the Papers in the Biological Sciences at DigitalCommons@University of Nebraska - Lincoln. It has been accepted for inclusion in Svata M. Louda Publications by an authorized administrator of DigitalCommons@University of Nebraska - Lincoln. 


\title{
SEED PREDATION AND SEEDLING MORTALITY IN THE RECRUITMENT OF A SHRUB, HAPLOPAPPUS VENETUS (ASTERACEAE), ALONG A CLIMATIC GRADIENT ${ }^{1}$
}

\author{
SVAŤA M. LOUdA ${ }^{2}$ \\ Biology Department, San Diego State University, San Diego, California 92182 USA, \\ and Division of Biological Sciences, University of California, \\ Riverside, California 92502 USA
}

\begin{abstract}
Haplopappus venetus is a characteristic shrub of the coastal sage scrub of southern California. Its relative frequency decreases rapidly and significantly from the coast to the central valleys of southern California. Insect damage to developing flowers and seeds is high (35-61\%). Experimental exclusion of predispersal flower and seed predators caused a significant increase in the number of viable seeds released because of: (1) a decrease in insect-caused abortion of flower heads $(11 \%),(2)$ an increase in pollination success (19\%), and (3) a decrease in damage to developing seeds $(104 \%)$. A significant and proportionate increase in the number of seedlings established at sites over the climatic gradient from coast to inland valleys followed the exclusion of seed predators. In the inland area, however, extremely high mortality among established seedlings prevented recruitment of juveniles. Mortality of established adult plants, in contrast, was higher at the coast than inland (41 vs. $31 \%$, respectively), suggesting that the geographic difference in the abundance of juveniles would persist. These results differ from those for a parallel experiment on $H$. squarrosus in which juvenile recruitment was determined by differential predispersal seed predation along the gradient and was not altered by differential mortality among seedlings. Consequently, I conclude that insect seed predation can be the critical factor limiting population recruitment, as in the case of $H$. squarrosus, but it need not be, as in the case of $H$. venetus. In the latter case, seedling mortality patterns, superimposed on seed predation, were critical to an explanation of plant recruitment and occurrence over the climatic gradient.
\end{abstract}

Key words: Asteraceae; gradient; Haplopappus, insect-plant interactions; plant population dynamics; seedling predation; seed predation.

\section{INTRODUCTION}

Predispersal seed predation by insects is a widespread, often severe source of early plant mortality (e.g., Salisbury 1942, Janzen 1969, 1971, Bohart and Koerber 1972, Harper 1977, Louda 1978, 1982a, b). The consequences of seed predation by native insects for the population dynamics of native plants, however, are not well known (Harris 1972, Harper 1977, Whittaker 1979).

Currently available evidence demonstrates: (1) that significant seed losses are caused by insect feeding (references above) and (2) that exclusion of flowerand seed-feeding insects leads to increased maturation and release of viable seed (Breedlove and Ehrlich 1968, 1972, Waloff and Richards 1977, Louda 1978, 1982a, $b$, Parker and Root 1981, S. Kinsman, personal communication). In addition, an increase in viable seed led to increased seedling establishment by a temperate shrub, Haplopappus squarrosus H. and A. (Louda 1978, 1982a) and contributed significantly to explaining the distribution of this species over a climatic gradient in southern California (Louda 1978, 1982b).

Several important questions remain. Two of these

\footnotetext{
${ }^{1}$ Manuscript received 20 February 1982; accepted 26 April 1982; final version received 28 May 1982.

${ }^{2}$ Present address: Duke University, Pivers Island, Beaufort, North Carolina 28516 USA.
}

are: (1) how consistent is the relationship between seed loss and juvenile recruitment among plant species, especially among related species in the same area, and (2) does severe seed predation necessarily determine population replacement rate, especially over the range of environmental conditions under which a plant species occurs?

The field experiments reported here address these questions for the interaction of another composite, Haplopappus venetus Blake, with its guild of flowerand seed-feeding insects. The experiment was designed: (1) to test the effect of predispersal seed predation on seed production and seedling establishment, (2) to evaluate the role of mortality in subsequent developmental stages on plant recruitment, and (3) to compare the results to those for the related, overlapping species, $H$. squarrosus. The results provide an experimental data base for the discussion of the more general questions posed.

\section{EXPERIMENTAL SySTEM \\ Study areas}

This study was conducted in coastal San Diego County, California, an area with a Mediterranean climate of cool, wet winters and hot, dry summers (Miller et al. 1977, Mooney 1977). The cismontane region of the county has been divided into four plant growing zones (Gilbert 1970; Fig. 1) which integrate annual pat- 


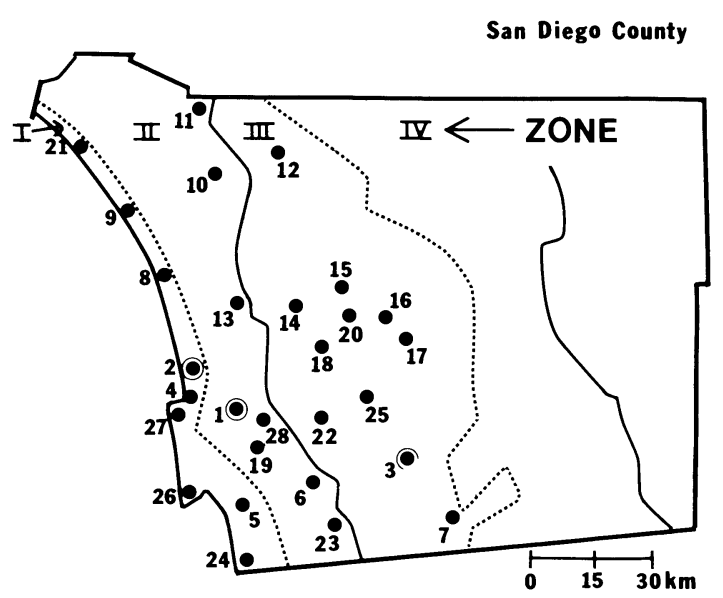

Fig. 1. Sampling and experimental sites for $H$. venetus in San Diego County, California, USA. The Pacific Ocean coastline is at left. North is at the top. San Diego County is divided into four roughly parallel climatic zones (I, II, III, IV) on the oceanic side of the peninsular range of coastal mountains. Experimental sites are circled.

terns of temperature and moisture (see Gilbert [1970] and Louda [1978, 1982b] for detailed description).

Haplopappus venetus occurs in the three zones nearest the ocean (Louda 1978). Observational data were collected at several sites, and experiments were done at a main site in each zone (Fig. 1). The maritime zone (Fig. 1: I) occurs in the plains and valleys adjacent to the ocean; it is dominated continuously by the maritime air mass and is characterized by summer fog. The main site in this zone was located on the southwest corner of the junction of Interstate Highway 5 and Carmel Valley Road in Del Mar, $24 \mathrm{~km}$ north of San Diego. The coastal zone (Fig. 1: II), which encompasses the bluffs, mesas, and valleys interior to zone $\mathrm{I}$, is also maritime in climate; however, conditions are more variable since the continental air mass predominates up to $25 \%$ of the time. The main study site in this zone was established in an arroyo of Murphy Canyon, along Interstate Highway $15,8 \mathrm{~km}$ north of the San Diego River. The transition zone (Fig. 1: III), the most inland zone in which $H$. venetus was observed, occurs in the central valley and foothill areas, which experience either an alteration of maritime and continental air masses or a continuous set of intermediate conditions. The main site in this zone was in Sloan Canyon, $0.5 \mathrm{~km}$ south of the junction of Sloan Canyon Road and Dehesa Road, $45 \mathrm{~km}$ east of the city of San Diego.

All of the sites were disturbed areas. Descriptive data and climatic parameters are presented in Louda (1978). The vegetation at the experimental sites was coastal sage scrub (e.g., Mooney 1977). The main shrubs were: Haplopappus venetus, Eriogonum fasciculatum, Baccharis sarathroides, and Artemesia californica (nomenclature follows Munz and Keck
1970). Shrub cover was similar among sites (28-36\%). Herb and grass cover varied from $60 \%$ in zone I to $34 \%$ in zone III (Louda 1978).

\section{The plant}

Haplopappus venetus subsp. vernonioides is characteristic of the coastal sage scrub, occurring from Monterey, California, to central Baja California, Mexico (Hall 1928, S. M. Louda, personal observation). It is a medium-sized $(<130 \mathrm{~cm}$ tall $)$ shrub which occurs throughout the coastal scrub, especially in disturbed places such as coastal bluffs, alluvial fans, arroyo bottoms, and overgrazed pastures.

Vegetative growth occurs in winter and spring. No vegetative reproduction was observed at my sites in San Diego County. Sexual reproduction begins in early summer with the initiation of flower head inflorescences (illustrated in Louda 1982c). The flower visitors observed include: Apis mellifera (Apidae), various microlepidoptera, flies, and a chrysidid wasp.

\section{Seed predators}

The predispersal flower and seed predators include flies, microlepidopterans, seed chalcids, a curculionid weevil, a lygaeid bug, and pollen-feeding thrips. Mites (Acarina) also occur and may be phytophagous.

Diptera.-The flies are typical flower-infesting Tephritidae, subfamily Tephritinae. These flies oviposit on the flower heads of the Asteraceae and feed on the developing fruit and seed (Christianson and Foote 1960). Although seven species of tephritids are reported for $H$. venetus in California (Foote and Blanc 1963, Wasbauer 1972), only three were reared from San Diego County material $(N=32$, Louda 1978). These were: Urophora formosa Coquillet (78.0\%), Trupanea femoralis Thompson (19.5\%), and Paroxyna murina Doane $(0.5 \%)$.

Lepidoptera.-The predominant microlepidopterans utilizing developing flowers, ovules, and seeds of $H$. venetus belong to three main families: Pterophoridae, Gelechiidae (Sophronia sp.; J. A. Powell, personal communication), and Tortricidae. The pterophorid larvae (details in Louda 1978) represent over half $(51.2 \%)$ of the identifiable moth larvae found in $H$. venetus flower heads $(N=127)$. Pterophorids are generally quite specific feeders (Borror and DeLong 1971).

Hymenoptera.-Two species of pteromalid wasps oviposit and develop on the immature heads and seeds. One causes urn-shaped galls on individual seeds and phyllaries. The other mines and galls the receptacle, causing all of the attached, developing florets and seeds to abort. Also, parasitoid and hyperparasitoid hymenopterans were reared from the flower heads. Two chalcidoids parasitize the tephritid flies: a eurytomid, Eurytoma sp., and a pteromalid (G. Gordh, personal communication), which occurs as either a gregarious parasitoid or, more likely, as a hyperparasitoid on the 
dipteran parasitoids. An ichneumonid wasp, in addition, was reared from the pupa of a microlepidopteran from a flower head.

Hemiptera.-A lygaeid, Nysius californicus (J. Hall, personal communication), is frequent on developing flower heads. The eggs and nymphs are found amid the florets in the head. Lygaeids are frequently important seed predators (Bohart and Koerber 1972). Their damage, however, has seldom been quantified since it is difficult to distinguish from physiologically caused abortion of developing flowers and seeds (Janzen 1971).

Coleoptera.-The late-season flower heads, developing along the proximal portion of the flowering branches, are frequently damaged and galled by the curculionid Anthonomus ochreopilosus Dietz (G. Marsh, personal communication). Beetle oviposition and larval development stimulates unusual proliferation of both the external phyllaries of the flower head and the internal receptacular tissue between developing seeds and ovules within the flower head (S. M. Louda and G. B. Harvey, personal observation).

Thysanoptera.-Several species of thrips occur in the flower heads. Adults of three species were found $(N=32)$ : Frankliniella occidentalis Pergando (62.5\%), F. minuta Moulton (31.2\%), and Thrips tabaci $(6.3 \%)$ (W. H. Ewart, personal communication). These genera are phytophagous flower feeders (Lewis 1973).

\section{METHODS \\ Geographic patterns}

Data were collected to quantify both the distribution and seed production effort of Haplopappus venetus and the occurrence of insects and seed destruction in each climatic zone of San Diego County. The methods were identical to those used to gather parallel data for the related species $H$. squarrosus (Louda 1978, 1982b).

For plant distribution and density, the presence of plants per $170 \mathrm{~m}$ ( 0.1 mile) long, $20 \mathrm{~m}$ wide, section of road (0.35-ha units) was recorded; effort was allocated in proportion to zone area $(N=2250$ units in zone I, 3950 in zone II, and 5050 in zone III). Two transects of $2 \times 2 \mathrm{~m}$ quadrats, averaging $30 \mathrm{~m}$ in length each, were used to quantify plant density at sampling sites (Fig. 1).

Seed production and destruction at each site were the product of: racemes per plant $(N=25$ plants per site), flower heads per raceme $(N=10$ racemes per plant), and number of seeds, damaged or undamaged, per flower head in three size- or age-categories $(N=$ 45 heads per plant). Insects were recorded and preserved or reared. Details are available in Louda (1978, 1982b).

\section{Experimental exclusion}

The procedure for the insecticide exclusion of flower- and seed-feeding insects for $H$. venetus was iden- tical to that which has been described for $H$. squarrosus (Louda 1978, 1982b). Six plots, two replicates of three plots each, were established at each main site (Fig. 1). A plot consisted of three experimental plants (185 branches per plot) in the center of a circle with a 5-m radius. Immature inflorescences were removed from all nonexperimental $H$. venetus individuals within the circle. Twelve surface soil samples were taken from each plot, and the plots were examined for established seedlings.

The experiment consisted of three treatments: (1) insecticide dissolved in water (Ortho Isotox ${ }^{\circledR}$, Chevron Chemical Company), (2) water only, and (3) nothing added. The insecticide combined low phytotoxicity with some systemic action and a surface residual (M. D. Atkins, personal communication). Treatments were assigned randomly to plots within a replicate and were begun on 22 July 1976. Treatments 1 and 2 were applied at the rate of $1 \mathrm{~L} /$ plant, biweekly, and were continued until 15 October 1976 , near the end of fruit maturation.

Seed production effort and treatment effectiveness were assessed at the end of the fruiting period (2-16 November) by recording: (1) racemes per plant, (2) flower heads per raceme, (3) unaborted heads per raceme, (4) flowers initiated per head, (5) seeds set per head (whether damaged or not), and (6) undamaged, matured seeds per head (Louda 1978). These were used to calculate the following for each plant: (1) flowers initiated (=maximum potential seeds), (2) seeds set, whether damaged or not, and (3) viable seeds available for release. Seeds were left to be dispersed by natural means, primarily wind.

The number of seedlings established for insecticidein-water and water-only treatments were counted in 84 quadrats $(50 \times 50 \mathrm{~cm})$ per plot $\left(21 \mathrm{~m}^{2}\right)$. These quadrats censused $41.7 \%$ of the $4 \mathrm{~m}$ radius inner circle (Louda 1978). Quadrats were examined for seedlings at the beginning of the experiment (August 1976) and at the end of the main period of germination (10-28 February 1977). Seedlings surviving to May were individually marked. The survivorship of seedlings was recorded quarterly from February 1977 until August 1978 and again in May 1979. The number surviving to enter the 1-yr-old class was defined as the number of juveniles recruited.

Since mortality in later life history stages could compensate for patterns in seed and seedling mortality, all established juveniles in the experimental plots and 50 established adults on an adjacent transect were marked at each main site and their survivorship recorded quarterly from 1977 to 1978 (Louda 1978).

\section{RESULTS}

\section{Geographic patterns}

The relative frequency of Haplopappus venetus decreased rapidly and significantly from the maritime zone 


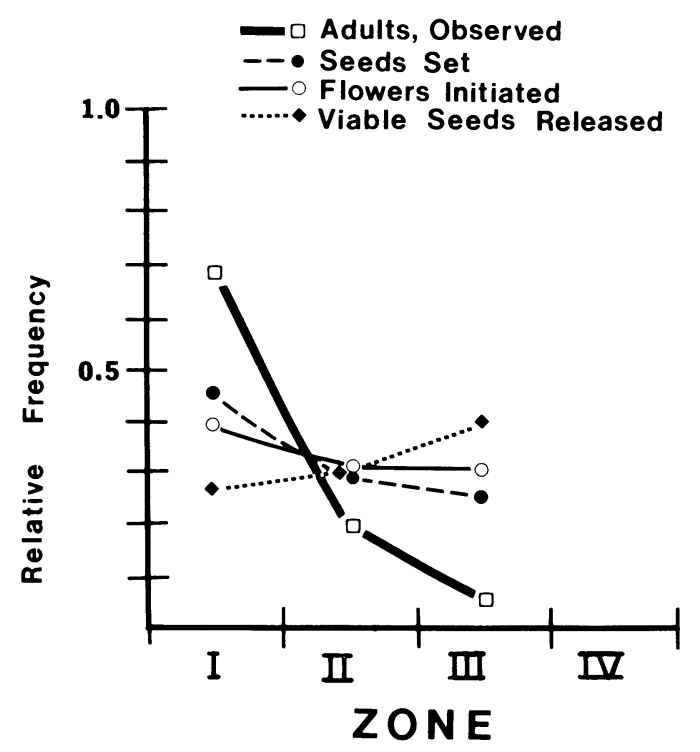

FIG. 2. Relative frequency of adult $H$. venetus plants observed in San Diego County, fall 1976, compared to three expected distributions based on: flowers initiated per plant, total seeds set per plant, and viable seeds released after seed predation.

(I) near the coast to the transition zone (III) of the central valleys and foothills (Fig. 2). The density of $H$. venetus at sampling sites was lower in the transition zone ( 1.5 plants $\left./ \mathrm{m}^{2}, \mathrm{SE}=0.19\right)$ than in the two more coastal zones ( 1.8 plants $/ \mathrm{m}^{2}, \mathrm{SE}=0.10$ and 0.16$)$, but the difference was not significant (two-level nested ANOVA, $F=0.29$ among zones). The major source of variation in sampled density was among sites rather than among zones (ANOVA, $F=10.89, P<.01$ ). Consequently, the product of frequency of occurrence and sampled density, a geographic estimate of relative occurrence, also showed the pattern illustrated in Fig. 2.

The initial information required to answer the question of the contribution of insect predation to the observed pattern of occurrence and abundance includes data on: flower initiation, seed-set, and seed destruction by insects along the gradient. These data represent maximum and observed seed production for plants in each zone under the existing environmental conditions and provide estimates of the expected distribution of plants among zones from three points in seed development (Fig. 2).

Flower initiation averaged: 97250 flowers per plant in zone I ( $N=9$ sites $), 69900$ flowers per plant in zone II $(N=8$ sites $)$, and 72230 flowers per plant in zone III $(N=11$ sites $)$; however, the differences in flower initiation among zones were not significant (KruskalWallis ANOVA, $H=3.97, .20<P<.10$ ). Seed-set per flower head was significantly higher at the coast (55.6\%, $\mathrm{SE}=1.12, N=6$ plants with 50 flower heads per plant) than in the two more inland areas $(49.3 \%$, $\mathrm{SE}=0.39$, in zone II; $44.6 \%, \mathrm{SE}=1.76$, in zone III; Kruskal-Wallis test, $H=8.19, P<.02)$.

The seed destruction rate of $60.7 \%$ in zone I was significantly greater (Kruskal-Wallis ANOVA, $\boldsymbol{H}=$ $8.33, .02<P<.01)$ than in zone II $(43.1 \%)$ or zone III $(34.8 \%)$ and led to a reversal of ordering among zones in the release of undamaged seeds (38 220 seeds in zone I, 39775 seeds in zone II, and 47095 seeds in zone III). However, the differences among zones in the number of viable seeds released after predation were not significant (Kruskal-Wallis ANOVA, $H=$ $0.44, .90<P<.80)$.

All three estimates of expected distribution of $H$. venetus over the gradient, based on flower and seed production (Fig. 2), predict a more even distribution along the gradient than is observed among adult plants. These geographic differences led to two questions which were examined in the experiment: (1) does predispersal seed predation influence seedling establishment, and (2) what limits juvenile recruitment and plant establishment at various sites along the gradient?

\section{Experimental exclusion}

Seed production.-Initial conditions were similar among treatments at all sites and among sites along the gradient. Plant sizes were comparable among treatments and among sites initially (Louda 1978: Fig. 8), and flower initiation was also similar (Table 1B). The number of seeds in the soil was low. Only one site, zone I, had any seeds in the preliminary soil samples $\left(\bar{x}=2.2\right.$ seeds $/ \mathrm{m}^{2}$, SE $=0.30, N=6$ plots with 12 samples per plot per site).

Flower initiation was relatively uniform over the climatic gradient (Fig. 2) and so was consistent with the geographic results. Differences among zones in the number of flowers initiated by either set of control plants were not significant (Table 1B); however, the insecticide-treated plants at the transition zone site (III) produced more flowers than did insecticide-treated plants in zones I and II (Table 1B). Several components of the flower production estimate varied. Insecticide-treated plants in zone III, compared to those in zones I and II (Table 2), had: (1) more flowering branches (Table 2A), (2) a higher number, but equal proportion $(92.6 \%)$, of unaborted flower heads on each branch (Table 2B, C), and (3) more flowers in each head (Table 2D). Insecticide application did not increase the number of flowers initiated compared to the control treatments overall (Table 1B).

The experiment was effective in increasing significantly the number of viable (matured, undamaged) seeds produced per plant; the increase was largest in the inland zone III (Table 1D). The increase in viable seeds produced by a sprayed plant combined: (1) more seeds being set by successful pollination of flowers (Table 1C) and (2) fewer developing flower heads and seeds lost to insects (Table 1A). These results combine 
TABLE 1. Insect damage and seed production by Haplopappus venetus over the climatic gradient in the experimental exclusion, 1976. $N=$ six plants for each treatment at each site. $* P=.05 ; *+P=.025 ; * *+P=.012$.

\begin{tabular}{|c|c|c|c|c|c|c|c|}
\hline \multirow[b]{4}{*}{ Parameter } & \multicolumn{6}{|c|}{ Treatment $\ddagger$} & \multirow[b]{4}{*}{$P \|$} \\
\hline & & & & & & & \\
\hline & \multicolumn{2}{|c|}{ Insecticide in water } & \multicolumn{2}{|c|}{ Water only } & \multicolumn{2}{|c|}{ Nothing added } & \\
\hline & $\bar{x}$ & SE & $\bar{x}$ & SE & $\vec{x}$ & SE & \\
\hline \multicolumn{8}{|c|}{ A. Insect-damaged heads $(\%)$} \\
\hline Zone I & 1.8 & $3.53^{*}$ & 66.4 & 4.75 & 71.4 & 2.35 & \\
\hline Zone II & 23.1 & 4.74 & 81.1 & 6.23 & 76.8 & 4.07 & \\
\hline Zone III & 14.6 & 3.00 & 63.1 & 2.83 & 60.4 & 1.96 & \\
\hline Grand mean, SE & 8.6 & 6.19 & 70.6 & 3.60 & 69.7 & 2.99 & $* * \dagger$ \\
\hline \multicolumn{8}{|c|}{ B. Flowers initiated per plant } \\
\hline Zone I & 39000 & 10175 & 40815 & 13500 & 36900 & 9590 & \\
\hline Zone II & 34825 & 6615 & 34100 & 9665 & 36250 & 7310 & \\
\hline Zone III & 56455 & $13625^{*}$ & 37165 & 9180 & 40590 & 9635 & \\
\hline Grand mean, SE & 43425 & 6625 & 37360 & 1940 & 37915 & 1350 & NS \\
\hline \multicolumn{8}{|l|}{ C. Seeds set per plant } \\
\hline Zone I & 21500 & 5840 & 17085 & 5720 & 15940 & 4230 & \\
\hline Zone II & 15955 & 3135 & 13730 & 4055 & 14275 & 3215 & \\
\hline Zone III & 28190 & $7150 *$ & 11385 & 3140 & 13075 & 3555 & \\
\hline Grand mean, SE & 21880 & 3535 & 14065 & 1655 & 14430 & 830 & $* \dagger$ \\
\hline \multicolumn{8}{|l|}{ D. Viable seeds per plant } \\
\hline Zone I & 21320 & 5790 & 10250 & 3565 & 9965 & 2820 & \\
\hline Zone II & 15135 & 2965 & 8060 & 2570 & 8920 & 2140 & \\
\hline Zone III & 27480 & $6915 *$ & 5890 & 1765 & 6690 & $1955^{*}$ & \\
\hline Grand mean, sE & 21310 & 3565 & 8065 & 1260 & 8525 & 965 & $* * \dagger$ \\
\hline
\end{tabular}

$\ddagger$ Extension of Median Test for differences among zones for each treatment (Siegel 1956; 179), with significance designation adjacent to the main source of variation.

$\S$ Mann-Whitney $U$ test for comparison of the two control treatments within each site, $U=4-5(P=.50-.65)$, NS in all cases.

Kruskal-Wallis ANOVA for comparison of pesticide exclusion and control treatments, for each parameter.

Tests done on arcsine-transformed proportions.

a moderate increase in the rate of pollination of flowers in a head (=increased proportion of seeds set per head, Table 2D, E) and a larger increase in the rate of seed escape from predators (=increased proportion of undamaged, matured seeds per head, Table 2D, F). Differences between control replicates in the maritime site (zone I) contributed to the variation there in loss to predation. In sum, the application of insecticide was successful in decreasing predispersal seed losses without decreasing pollinator effectiveness.

Seedling establishment and survival.-The increase in the number of seeds set by a plant sprayed with insecticide (Table 1C) and remaining undamaged (Table 1D) led to a significant increase $(P<.01)$ in the number of seedlings established (Table 3A). This increase was proportional to the increase in viable seeds. The exclusion led to a significant increase (MannWhitney $U$ test $P<.01)$ in seedling density at all distances out from the central, experimental plants at both sites (Fig. 3). Since few seeds or seedlings were present initially, seed or seedling supply present at the start of the experiment cannot account for these results. Also, since the number of viable seeds released for each seedling established did not differ between treatments within each zone (Table 3B), insecticide interference in germination and establishment is unlikely. These data do, however, suggest that seed predation imposed a cost. It took three times as many flowers, and twice as many pollinated ones, to produce a successful seedling when predispersal predators were present.

Overall seedling survivorship was low $(0.92 \%, N=$ 6177 seedlings), particularly in the first (spring) quarter (Fig. 4). The overall survivorship was composed of the relatively high survival rate of $1.73 \%(N=3180$ seedlings) at the maritime (I) site and the low one of $0.03 \%$ $(N=2937$ seedlings) at the inland transition (III) site. After $1 \mathrm{yr}, 98.6 \%$ of the seedlings surviving $(N=56)$ were at the coast; most of these, $98.2 \%$, were in insecticide plots. Since the proportion of germinated seedlings that survived the year was similar among treatments (Louda 1978) $(1.7 \%$ in zone $\mathrm{I}, 0.03 \%$ in zone III), insecticide application did not change seedling survivorship. Thus, establishment responded to an increase in viable seeds after predation, especially in zone III (Table 3D). Seedling survivorship was independent of initial seedling density (Table 4).

The seedlings that survive to the end of the 1st yr 
TABLE 2. Components of plant performance over the gradient in the experiment $(N=$ number for each treatment at each site).

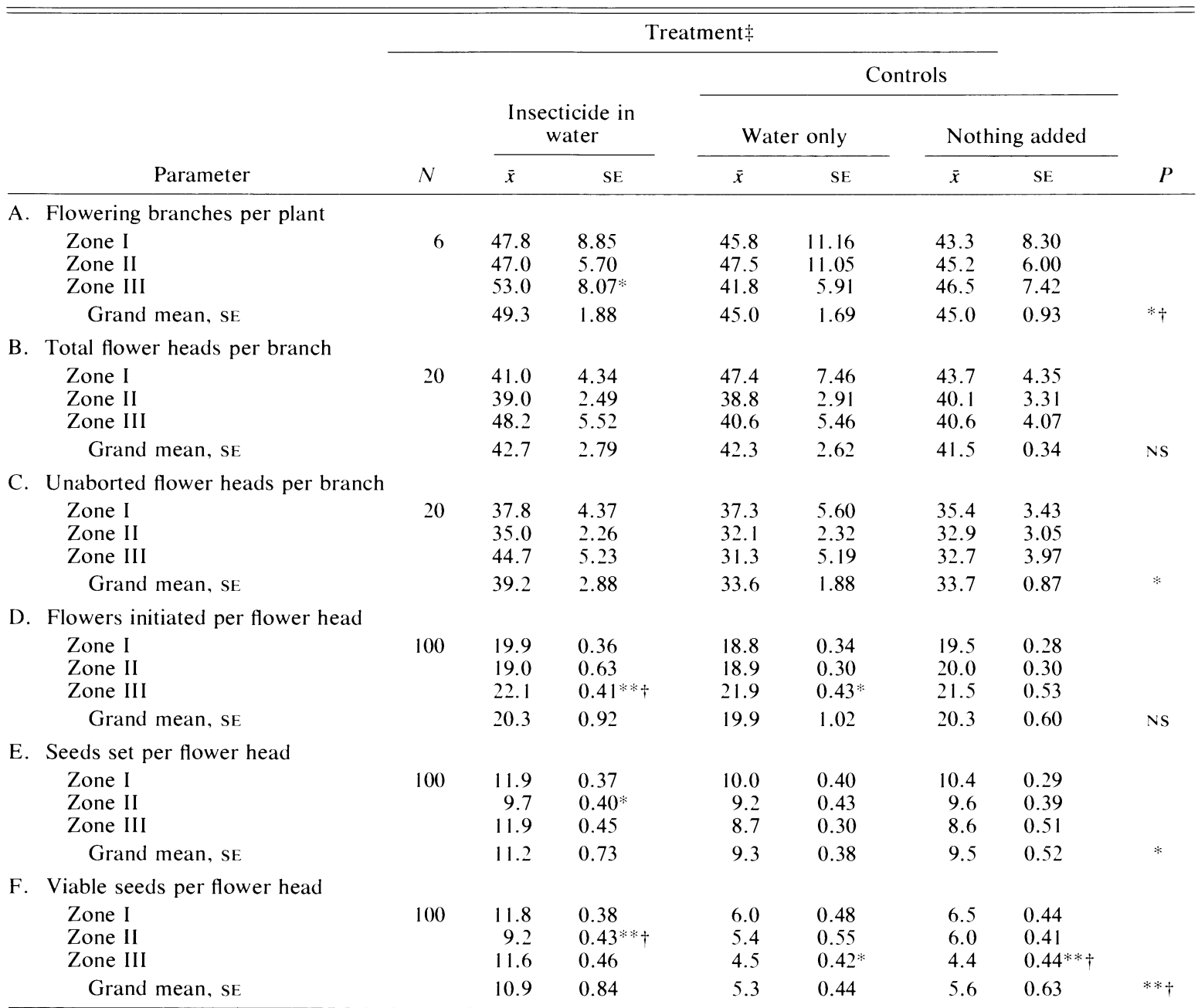

$¥$ Significance of differences tested using extension of Median Test, or Mann-Whitney $U$ test after application of KruskalWallis ANOVA, as in Table $1 ;{ }^{*} P=.05 ; *+P=.025 ; * *+P=.012$.

become juveniles which have been recruited into the population. Insecticide treatment led to a significant increase in the number of juveniles recruited per plant at the coast (zone I) and recruited overall (Table 3C). The increase was proportional to that in viable seeds after predation at the coastal (I) site but not at the inland one (Fig. 5), where seedling mortality was more severe (Fig. 4). Significantly more seedlings (chi-square test, $\left.\chi^{2}=315.4, P<.001\right)$ disappeared at the zone III site $(73.6 \%, N=782$ seedlings) than at the zone I site (26.4\%) during the spring between March and May 1977, when the fastest decline in numbers occurred. More small mammals were trapped at the zone III site than at the zone I site in April 1977 (L. Day and S. M. Louda, personal observation). In addition more lagomorphs, and larger small mammals such as ground squirrels, were observed there than at the coast ( $\mathrm{S}$.
M. Louda, personal observation). Together these data suggest vertebrate herbivore pressure was probably higher at the inland site.

Subsequent density-dependent mortality might compensate for initial differences between treatments. In this case, it did not. The densities of seedlings established in the insecticide exclusion treatments were high $\left(53.2-59.1\right.$ seedlings $\left./ \mathrm{m}^{2}\right)$ but led to densities of juveniles that were below the average density of adults (Table 5). Seedling density on control plots was also relatively high initially $\left(10.8-22.6\right.$ seedlings $\left./ \mathrm{m}^{2}\right)$ but led to very low or no juvenile recruitment $(0-0.3$ juveniles/ $\mathrm{m}^{2}$ ). Initial densities of established adult and juvenile plants were similar between treatments (Table 5; Louda 1978). Mortality of established adults and juveniles, in addition, was similar between zones: 42.9 and $35.5 \%$ for juveniles in zones I $(N=156)$ and III $(N=62)$, 
TABLE 3. Seedling establishment and juvenile recruitment in the experiment. Zone II site was bulldozed in December 1976 before seedling establishment.

\begin{tabular}{|c|c|c|c|c|c|}
\hline \multirow[b]{3}{*}{ Parameter } & \multicolumn{4}{|c|}{ Treatment } & \multirow[b]{3}{*}{$P^{*}$} \\
\hline & \multicolumn{2}{|c|}{ Insecticide in water } & \multicolumn{2}{|c|}{ Water only } & \\
\hline & $\bar{x}$ & $\mathrm{SE}$ & $\bar{x}$ & $\mathrm{SE}$ & \\
\hline \multicolumn{6}{|c|}{ A. Seedlings established per plant } \\
\hline Zone I & 372 & 110.3 & 169 & 99.3 & .01 \\
\hline Zone III & 414 & 139.5 & 76 & 23.3 & .01 \\
\hline Grand mean, SE & 393 & 73.6 & 122 & 49.7 & .01 \\
\hline \multirow{2}{*}{\multicolumn{6}{|c|}{$\begin{array}{l}\text { B. Production per seedling established } \\
\text { Flowers initiated per seedling }\end{array}$}} \\
\hline & & & & & \\
\hline Zone I & 44 & 11.5 & 91 & 30.0 & .05 \\
\hline Zone III & 57 & 13.8 & 206 & 50.9 & .01 \\
\hline Grand mean, SE & 46 & 6.5 & 123 & 19.3 & .02 \\
\hline \multicolumn{6}{|l|}{ Seeds set per seedling } \\
\hline Zone I & 24 & 6.6 & 38 & 13.5 & NS \\
\hline Zone III & 29 & 7.3 & 63 & 17.5 & .05 \\
\hline Grand mean, SE & 23 & 3.5 & 46 & 7.6 & .05 \\
\hline \multicolumn{6}{|c|}{ Viable seeds per seedling } \\
\hline Zone I & 24 & 6.5 & 23 & 7.9 & NS \\
\hline Zone III & 28 & 7.1 & 33 & 9.9 & NS \\
\hline Grand mean, SE & 22 & 3.5 & 46 & 7.6 & .05 \\
\hline \multicolumn{6}{|c|}{ C. Juveniles recruited per plant } \\
\hline Zone I & 7.2 & 5.05 & 2.0 & 0.96 & .05 \\
\hline Zone III & 0.2 & 0.05 & 0.9 & $\cdots$ & NS \\
\hline Grand mean, SE & 3.7 & 1.82 & 1.0 & 0.51 & .05 \\
\hline
\end{tabular}

* Wilcoxon test of difference between paired central square metres and paired quadrats of replicate plots $(N=10$ paired estimates per zone).

respectively $\left.\chi^{2}{ }_{1}=0.84, P>.1\right)$ and 40.0 and $26.0 \%$ for adults in zones I $(N=50)$ and III $(N=50)$, respectively $\left.\chi^{2}{ }_{1}=2.30, P>.10\right)$, suggesting that subsequent mortality over the gradient would not change the comparative conclusions based on the experimental results.

TABLE 4. Survival of Haplopappus venetus seedlings in relation to initial seedling density at the Maritime (zone I) site, 1976-1977. At the Zone III site only one seedling survived the year to be recruited to the population as a juvenile; initial density in that quadrat of the spray plot was 19 seedlings.

\begin{tabular}{cccc}
\hline \hline $\begin{array}{c}\text { Initial num- } \\
\text { ber of } \\
\text { seedlings } \\
\text { per } 50 \times 50 \mathrm{~cm} \\
\text { quadrat }\end{array}$ & $\begin{array}{c}\text { Number } \\
\text { of } \\
\text { quadrats* }\end{array}$ & \multicolumn{2}{c}{$\begin{array}{c}\text { Number of seedlings } \\
\text { surviving per quadrat } \dagger\end{array}$} \\
\cline { 2 - 4 } $1-10$ & 5 & $\bar{x}$ & SE \\
$11-20$ & 6 & 1.0 & 0.00 \\
$21-30$ & 9 & 1.6 & 0.17 \\
$31-40$ & 4 & 2.0 & 0.24 \\
$41-50$ & 4 & 1.2 & 0.71 \\
$51--60$ & 4 & 2.2 & 0.63 \\
$61-70$ & 1 & 2.0 & $\cdots$ \\
$71-80$ & 0 & $\cdots$ & $\cdots$ \\
$81-90$ & 1 & 6.0 & $\cdots$ \\
$>90$ & 0 & & \\
\hline
\end{tabular}

* All quadrats with any juveniles recruited at $1 \mathrm{yr}$.

+ Kruskal-Wallis test, within site at zone $1, P>.05$.



FIG. 3. Distribution of seedlings established in marked quadrats by the central experimental plants by distance from the center, independent of compass direction of established seedling (Mann-Whitney $U$ test, ${ }^{*}=P<.05$ ). 


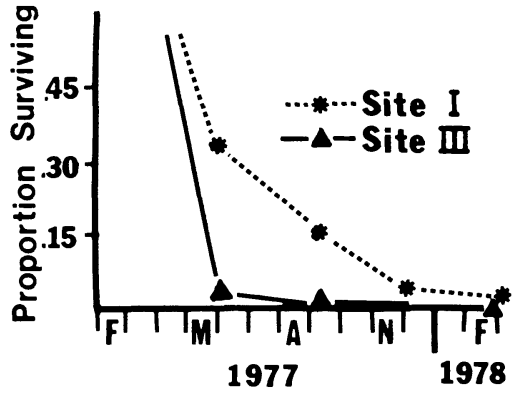

FIG. 4. Cohort survivorship for all $H$. venetus seedlings in the experiment at the maritime (I) and transition (III) zone sites. No significant differences were found between treatments within either site (Louda 1978: Fig. 21).

\section{Discussion}

\section{Production of viable seed}

Inflorescence arthropods had a significant impact on both the number of seeds set and the number matured undamaged for each plant. Insecticide reduction of flower- and seed-feeding insects increased: (1) the number of small flower heads which escaped insectcaused abortion (Table 1), (2) the number of flowers which were pollinated (=seeds set) per flower head (Table 2) and per plant (Table 1), and (3) the number of developing seeds which matured without insect damage. However, the proportionate decrease in abortion of early flower heads with insecticide exclusion, $11 \%$ for Haplopappus venetus (Table 2), was much less than observed for $H$. squarrosus $(45.4 \%$ : Louda 1978, 1982b). Data from the geographical sam-
Table 5. Densities of Haplopappus venetus at successive developmental stages under unmanipulated and manipulated conditions.

\begin{tabular}{|c|c|c|c|c|c|}
\hline & \multicolumn{4}{|c|}{ Density } & \multirow[b]{3}{*}{$P^{*}$} \\
\hline & \multicolumn{2}{|c|}{$\begin{array}{l}\text { Control plots } \\
\text { or zone mean }\end{array}$} & \multicolumn{2}{|c|}{$\begin{array}{l}\text { Insecticide } \\
\text { plots }\end{array}$} & \\
\hline & $\bar{x}$ & SE & $\bar{x}$ & SE & \\
\hline \multicolumn{6}{|l|}{ Zone I } \\
\hline Seedlings & 22.6 & 15.85 & 53.2 & 15.75 & .05 \\
\hline Juveniles & 0.3 & 0.20 & 1.0 & 0.93 & .05 \\
\hline Adults: main site & 1.4 & 0.12 & 1.4 & 0.11 & NS \\
\hline Adults: zone mean & 1.8 & 0.10 & & & \\
\hline Adults: high density & 2.1 & 0.17 & & & \\
\hline \multicolumn{6}{|l|}{ Zone III } \\
\hline Seedlings & 10.8 & 3.30 & 59.1 & 19.90 & .01 \\
\hline Juveniles & 0.0 & 0.00 & 0.05 & 0.05 & NS \\
\hline Adults: main site & 1.4 & 0.10 & 1.4 & 0.13 & NS \\
\hline Adults: zone mean & 1.5 & 0.09 & & & \\
\hline Adults: high density & 2.0 & 0.16 & & & \\
\hline
\end{tabular}

* Mann-Whitney $U$ test on matched quadrats in the experiment.

ple were consistent with the experimental pattern. Damage to small heads of $H$. venetus was low; it only reached $20.0 \%$ (zone II), compared to $51.2 \%$ on $H$. squarrosus (Louda 1978, 1982b).

Thus, less damage is done by insects to small, early flower heads on $H$. venetus than to those of $H$. squarrosus. Two factors contribute to this difference. First, small heads of $H$. venetus appear better protected than those of $H$. squarrosus. The phyllaries surrounding the developing flower head of $H$. venetus were more

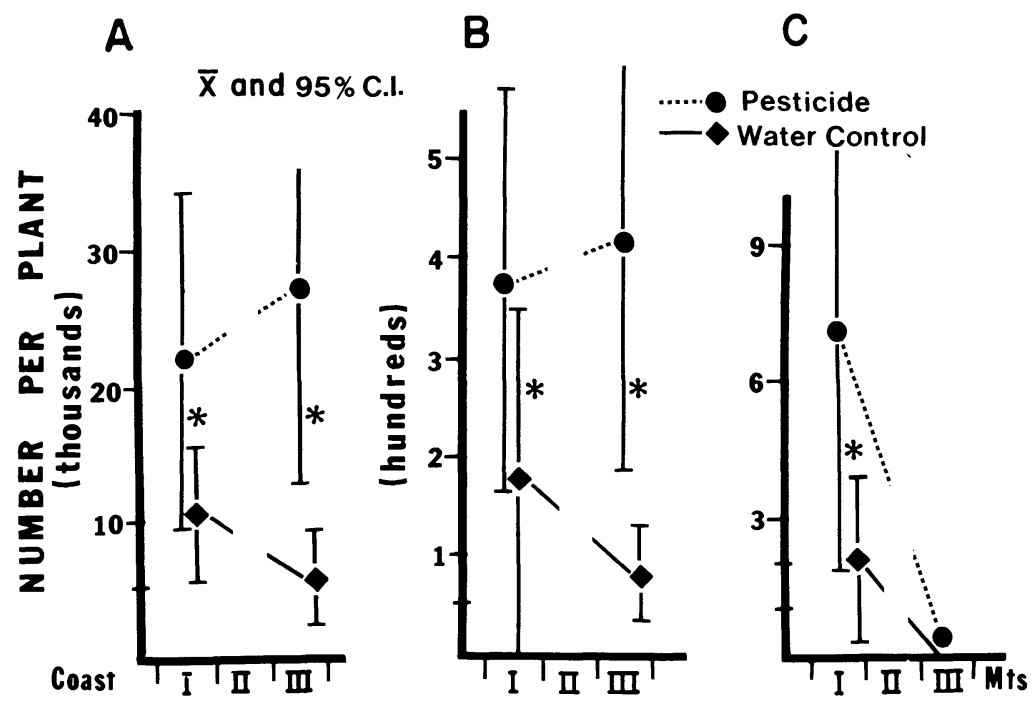

\section{CLIMATIC ZONE}

FIG. 5. Experimental response along the gradient to exclusion of predispersal flower and seed predators for each life history stage: (A) viable seeds released, (B) seedlings established, and (C) juveniles recruited at 1 yr, when a new seedling cohort will be establishing (Wilcoxon Matched Pairs Signed-Rank test, $*=P<.05$ ). 
glandular than those of $H$. squarrosus. Heads of $H$. venetus had resinous, tightly imbricated phyllaries, which completely enclosed the floral buds for a relatively long time in head development. These heads appeared less susceptible to early attack than did the less resinous, more loosely imbricated, earlier-opening heads of $H$. squarrosus. Few oviposition scars were found, for example, on phyllaries of $H$. venetus compared to phyllaries of $H$. squarrosus (S. M. Louda, personal observation). Second, comparative phenology of flower head development also influenced the level of insect-caused abortion of developing heads. For both species, the zone which had the highest proportion of small, early flower heads attacked and aborted was also the zone with the earliest production of flower heads: zone II for $H$. venetus and zone I for $H$. squarrosus. Furthermore, head development by $H$. venetus lagged that of $H$. squarrosus by $2-4 \mathrm{wk}$ (S. M. Louda, personal observation). Thus a third possible factor, sequential use by overlapping seed predators, does not appear important here. Although some of the seed predators, such as the tephritid Urophora formosa or the gelechiid Sophronia sp., used both species of Haplopappus, damage was lower (20 vs. $51 \%$ ) rather than higher on small heads of the lateflowering species, $H$. venetus.

Flower- and seed-feeding insects interfered with pollination, as well as destroyed seeds on $H$. venetus, but not on $H$. squarrosus (Louda 1978, 1982b). Both the 2.3-fold gain in seeds set per plant for $H$. venetus at Sloan Canyon (III) and the 1.3-fold increase at Carmel Valley (I) were significant (Table 1). A greater number and proportion of seeds were set per head at both sites (Table 2). Two factors contributed to the increase in the rate of pollination. First, pollen-feeding thrips were common in flower heads on unsprayed $H$. venetus individuals, and there was evidence of damage to flower tissues on these plants. Second, inflorescence spiders (Peucetia viridans Hentz, Oxyopidae: M. H. Greenstone, personal communication) and nectar-feeding ants were more frequent on $H$. venetus than on H. squarrosus (Louda 1982c). Elimination of spiders and ants from inflorescences should have increased duration, and perhaps frequency, of flower visitation by potential pollinators (Bentley 1976, Morse 1979, Louda 1982c).

Most important, the exclusion of seed predators increased the number of viable seeds released per plant: 2.4 times for $H$. venetus (Table 1) and 6.5 times for H. squarrosus overall (Louda 1978, 1982b: Table 3). The increase for $H$. venetus was accounted for by a significant reduction in damage: (1) to small flower heads and (2) to developing seeds, as well as an increase in successful pollination of each head (Tables $1,2)$. It is clear that the complex of inflorescence arthropods had a major impact on the seed production realized by individuals of both species of Haplopappus at all sites along the gradient from coast to inland.

\section{Recruitment within sites}

The differences in seedling and juvenile recruitment observed between treatments cannot be explained by either physical factor differences or competition. Physical factors were similar within sites; treatments were assigned randomly to plots within replicates. Nor does competition seem likely as an explanation of the experimental results. It took an equal number of viable (undamaged) seeds to establish a seedling in both treatments (Table 3). Adult densities in the experiment were similar between treatments and sites. Cover was similar. Seedling density was low in general, and seedling survivorship in the experiment was higher, not lower, at high seedling densities (Table 4). In sum, alternative hypotheses do not provide the clearest explanation for the differences between insecticide and control plots at each site.

\section{Recruitment along the gradient}

Predispersal seed predation was important for $H$. venetus seedling numbers. Removing seed predators increased seedling establishment significantly and proportionately at both sites (Fig. 5) and also increased juvenile recruitment at the coast (Table 3). However, in contrast to the results for $H$. squarrosus (Louda 1978, 1982b), differential seedling mortality, rather than differential seed predation, was more important in determining the pattern of juvenile recruitment by $H$. venetus along the gradient. The experiment showed the following relationships with the exclusion of predispersal predators. The increase in viable seeds after predation was greatest inland (zone III), so that the production of viable seeds per plant became uniform over the gradient. The rate of seedling establishment was similar between coastal and inland sites. Therefore, total seedling establishment was also similar. Since the seedling mortality rate did not differ between pesticide and control plots, higher numbers of seedlings led to higher numbers of juveniles, particularly at the coastal site (I). Seedling mortality for $H$. venetus, however, was especially severe inland.

The estimates of mortality for sequential stages suggest that physical and biotic factors interact to determine the difference in recruitment along the climatic gradient. Insect seed predators reduce seedling recruitment along the gradient. Physical factors and vertebrate herbivory reduce seedling survival more in the inland area, where seedling mortality and disappearance were much more severe than at the coast. A higher proportion of seedlings are in zone III than in zone I ( 99.97 vs. $98.27 \%$ ), and more of those that die actually disappear or are removed in zone III than in zone I $(73.6$ vs. $26.4 \%)$. In addition the higher mortality and disappearance rates are superimposed on losses to seed predators (Fig. 5). Therefore, the higher than expected relative frequency and abundance of adult $H$. venetus observed in the maritime zone (I), and the lower than 
expected frequency of adults in the transition zone (III; Fig. 2) can be explained as the result of differential seedling mortality in the inland transition zone.

The outcome for $H$. venetus extends the results of the parallel test on $H$. squarrosus in the same region (Louda 1978, 1982b) and substantiates the importance of predispersal seed predation by insects in plant recruitment. The additional results for $H$. venetus also demonstrate that the observed occurrence of a plant subject to seed predation may reflect differential loss of individuals at subsequent stages among sites superimposed on that seed loss. Seedling disappearance and mortality, in this case, were significantly greater in the inland portion of the climatic gradient. This mortality was superimposed on a greater response to exclusion of seed predators in the inland area. The resulting pattern at the end of the year, one that paralleled the pattern of adult occurrence, was the direct effect of much higher seedling mortality in the inland area (III) superimposed on significant losses to flower and seed predators.

Thus, these results suggest that: (1) seed predation consistently caused a proportionate reduction in seedling establishment for both species at all sites, but seed predation alone was not a consistent predictor of juvenile recruitment; and (2) seed predation, while important in recruitment in one portion of the gradient, could not by itself explain the pattern of occurrence of $H$. venetus along the gradient. As in the case of $H$. squarrosus, differential mortality was crucial to the observed pattern along the gradient. However, for $H$. venetus, it was differential seedling mortality, probably by vertebrate herbivores, rather than differential seed mortality by insect seed predators, that best explained the pattern of recruitment and occurrence along the gradient.

\section{ACKNOWLEDGMENTS}

I thank: W. W. Murdoch and R. D. Goeden, who interested me in the question; J. H. Connell, R. T. Paine and P. K. Dayton, who taught me the experimental approach; B. D. Collier, R. F. Luck and P. H. Zedler, who alternately guided, challenged, and encouraged me; M. D. Atkins, C. F. Cooper, G. W. Cox, T. A. Ebert, D. A. Farris, L. R. Fox, W. E. Hazen, J. Kummerow, and D. Potts, all of whom provided experimental or analytical advice; J. Clark, W. H. Ewart, G. Gordh, J. Hall, R. W. Hodges, G. Marsh, and J. A. Powell, who made or verified insect identifications; M. H. Greenstone, who identified the spiders; J. Antonovics, P. R. Atsatt, S. N. Handel, S. Mazer, K. R. McKaye, J. E. Rodman, and R. B. Root, who contributed discussion which improved the manuscript; and all the friends and family who helped gather data, especially G. A. Baker and G. B. Harvey. The research was funded by the State of California, the Joint Doctoral Program in Ecology (SDSU/UCR), and a National Science Foundation Doctoral Dissertation Improvement Grant, and it was written up with the support of National Science Foundation Grant Number DEB-811106.

\section{Literature Cited}

Bentley, B. L. 1976. Plants bearing extrafloral nectaries and the associated ant community: interhabitat differences in the reduction of herbivore damage. Ecology 57:815-820.
Bohart, G. E., and T. W. Koerber. 1972. Insects and seed production. Pages 1-50 in T. T. Kozlowski, editor. Seed biology. Volume 3. Academic Press, New York, New York, USA.

Borror, D. J., and D. M. DeLong. 1971. An introduction to the study of insects. Holt, Rinehart, and Winston, New York, New York, USA.

Breedlove, D. E., and P. R. Ehrlich. 1968. Plant-herbivore coevolution: lupines and lycaenids. Science 162:671-672.

Breedlove, D. E., and P. R. Ehrlich. 1972. Coevolution: patterns of legume predation by a lycaenid butterfly. Oecologia (Berlin) 10:99-104.

Christianson, L. D., and R. H. Foote. 1960. Biology of fruit flies. Annual Review of Entomology 4:171-192.

Foote, R. H., and F. L. Blanc. 1963. The fruit flies of Tephritidae of California. Volume 7. Bulletin of the California Insect Survey. University of California Press, Berkeley, California, USA.

Gilbert, D. E. 1970. California plant climates. Pages 13-17 in D. H. Close, editor. Climates of San Diego County. Agricultural Extension Service, University of California, San Diego, California, USA.

Hall, H. M. 1928. The genus Haplopappus. Publication number 389, Carnegie Institute, Washington, D.C., USA.

Harper, J. L. 1977. The population biology of plants. Academic Press, New York, New York, USA.

Harris, P. 1972. Insects in the population dynamics of plants. Pages 201-210 in H. F. van Emden, editor. Insect/plant relationships. Blackwell Scientific Publications, Oxford, England.

Janzen, D. H. 1969. Seed-eaters versus seed size, number, toxicity and dispersal. Evolution 23:1-27.

1971. Seed predation by animals. Annual Review of Ecology and Systematics 2:465-492.

Lewis, T. 1973. Thrips: their biology, ecology and economic importance. Academic Press, New York, New York, USA.

Louda, S. M. 1978. A test of predispersal seed predation in the population dynamics of Haplopappus (Asteraceae). Dissertation. University of California, Riverside, California, USA, and San Diego State University, San Diego, California, USA.

1982a. Limitation of the recruitment of the shrub Haplopappus squarrosus (Asteraceae) by flower- and seedfeeding insects. Journal of Ecology 70:43-53.

1982b. Distribution ecology: variation in plant recruitment over a gradient in relation to insect seed predation. Ecological Monographs 52:25-41.

1982c. Inflorescence spiders: a cost/benefit analysis for the host plant, Haplopappus venetus Blake (Asteraceae). Oecologia (Berlin) 55: 185-191.

Miller, P. C., D. E. Bradbury, E. Hajek, V. LaMarche, and N. J. W. Thrower. 1977. Past and present environment. Pages 27-72 in H. A. Mooney, editor. Convergent evolution in Chile and California: Mediterranean climate ecosystems. Dowden, Hutchison, and Ross, Stroudsburg, Pennsylvania, USA.

Mooney, H. A. 1977. Southern coastal scrub. Pages 471489 in M. Barbour and J. Major, editors. Terrestrial vegetation of California. Wiley-Interscience, New York, New York, USA.

Morse, D. H. 1979. Prey capture by the crab spider Misumena calycina (Araneae: Thomisidae). Oecologia (Berlin) 39:309-319.

Munz, P. A., and D. C. Keck. 1970. A California flora. University of California Press, Berkeley, California, USA.

Parker, M. A., and R. B. Root. 1981. Insect herbivores limit habitat distribution of a native composite, Machaeranthera canescens. Ecology 62:1390-1392.

Salisbury, E. J. 1942. The reproductive capacity of plants: studies in quantitative biology. Bell, London, England. 
Waloff, N., and O. W. Richards. 1977. The effect of insect fauna on growth, mortality and natality of broom, Sarothamnus scoparius. Journal of Applied Ecology 14:787798.

Wasbauer, M. S. 1972. An annotated host catalog of the fruitflies of America north of Mexico (Diptera: Tephritidae). Occasional papers number 19, Bureau of Entomolo- gy, California State Department of Agriculture, Sacramento, California, USA.

Whittaker, J. B. 1979. Invertebrate grazing, competition and plant dynamics. Pages 207-222 in R. M. Anderson, B D. Turner, and L. R. Taylor, editors. Population dynamics. British Ecological Society symposium number 20. Blackwell Scientific Publications, Oxford, England. 